\title{
洋上風力発電（着底式）の現状と展望
}

\section{Current states and future prospects of sea bottom mounted offshore wind turbines}

\section{1. まえがき}

現在, 風力発電の導入量は世界全体で 4,800 万 $\mathrm{kW}$ を超え, 量と質の点で優れる海上風を利用する洋上風 力発電施設が 1991 年ころからオランダやデンマーク で建設されるようになった。わが国でも，海に臨んだ 風況の優れる沿岸や港湾域の陸域に建設され, 2003 年ころから北海道瀬棚町 (設備容量 1.3MW) や山形県 酒田港(同 16MW) など防波堤内であるが, 海に風力発 電が建設された（図-1 参照のこと）。

ここでは, ヨーロッパで展開されている着底式洋上 風力発電の現状等を紹介しながら,さらにわが国の海 岸地形等の特徴や最近の研究成果を踏まえ, 今後の洋 上風車の展望を述べたい。

\section{2. 洋上風力発電の現状}

2.1 ヨーロッパにおける洋上風力発電

デンマークや英国にでは, 100MW を超える大規模な 洋上於トファームが建設されている。表-1 にあるように， アイルランドの Arklow 堆では 525MW と大規模な計画 がなされ, 2003 年にその一期分が竣工した。

これらは、いずれも遠浅な海岸の海底に固定される 着底式洋上風力発電施設である。洋上風車は, 最初才 ランダの湖沼などの内海から設膡され，次第に外洋

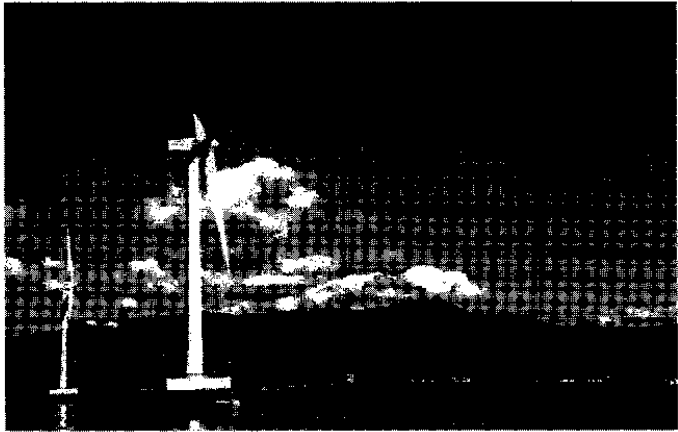

図-1 北海道瀬棚町（上から風車, タワー,水中基䃈）

に向かった歴史があり，最近の大規模なウイドファームに は離岸距離 $20 \mathrm{~km}$, 設置される水深も $20 \mathrm{~m}$ に達するもの もでてきた。離岸距離は海底送電ケーブルの敷設費上 昇要因となるが,この事例は大型機の発達により採算 性が成立するようになりつつあることを示唆する。

表-1 北欧における大規模洋上方仆゙ファームの立地

\begin{tabular}{|l|c|c|c|c|}
\hline 洋上 windfarm & $\begin{array}{l}\text { 離岸距 } \\
\text { 離(km) }\end{array}$ & $\begin{array}{l}\text { 水深 } \\
(\mathrm{m})\end{array}$ & $\begin{array}{l}\text { 容量 } \\
(\mathrm{MW})\end{array}$ & $\begin{array}{l}\text { 竣工 } \\
(\text { 年 })\end{array}$ \\
\hline Horns Rev(DK) & $14-20$ & $6-12$ & 160 & 2002 \\
\hline North Hoyle(英国) & 6 & $10-20$ & 60 & 2003 \\
\hline Arklow Bank(IRE) & 10 & 5 & 25 & 2003 \\
\hline Nysted(DK) & 10 & $5-9.5$ & 165.6 & 2004 \\
\hline
\end{tabular}

*1 東海大学 海洋学部 海洋土木工学科 教授

Professor, Department of Ocean Civil Engineering, School of Marine Science \& Technology, Tokai University 
大型機導入の背景には, 洋上は騒音影響等の問題が 少ないこと,大型建設機械が使用できること, 適確な 風車配置ができる広大な海域が確保できやすいこと， 等から送電ケーブルや水中基䃈などにかなりのコス 卜増があっても発電コストを低減できることにある。

実際, 使用されている発電機は Horns 礁, North Hoyle で 2MW, Nysted で2.3MW, Arklow 堆で 3.6 MW 機と大容量であり，それぞれは欧米の風車メーカーで あるVestas，Bonus 及び GE 社により製造された。

将来的には, $5 \mathrm{MW}$ 機が洋上でも普及し始め, 2010 年 には世界の洋上で 6,000 万 $\mathrm{kW}$ W設備容量に達すると ヨーロッパ風力協会 EWEA は予測している。

\section{2 海洋石油ガス開発産業からの技術移転}

北海の洋上風力の展開が着実に進められている背 景には, 海底油田ガス開発で培った海洋建設技術の洋 上風車への技術移転がある。その石油ガス関連産業と 風車産業間で相互交流が活発化す機運にあるので ${ }^{1)}$, 幾分紙面を割いてふれておきたい。

1970 年ころから始まった北海の海底ガス・油田は 衰退期に入り採算性の低い,いわゆるマージナル田が 開発されている。このような中, 固定式生産プラット フォームが当地では 600 基余り建設されてきたが, 一部では撒去もされている。その一つであるスコット ランド北東部沖 $25 \mathrm{~km}$ に位置する Beatrice 油田では, 近傍に $5 \mathrm{MW}$ 風車 2 機を設置し, 既存の 2 基のプラット フォームを発電基地として再利用する計画が進行し ている。

石油ガス関連産業は, 長い開発の経緯があるために 取り巻く規制や制約が今ではそれほど厳しくなく,か つ金・物・人の面で潤沢である。もう一方の風車産業 は, 関わるプロジェクトの規模がさほど大きくなく， 許認可の申請や環境問題へのきめ細かい対応が必要 であり，その上相当なコスト皠隇を図っていかねばな らない状況にある。かように, 同じ海洋産業でも歴史 や企業環境が異なるが; 新しい産業と在来の産業が共 通する海洋建設技術を通して結びっこうとしている。

これにとどまらず, 浮体式風車の建設を志向する 大水深の海岸が多い南欧や米国でも， $1,000 \mathrm{~m}$ 級の海 まで制霸した石油ガス関連技術を活用する研究が始 まっている。以下, 具体的な事例を紹介したい。

\section{1）建設費の縮減工法}

洋上風車は, 風車とそれを載せる支持構造, それら を支える水中基礎からなる。ヨーロッパではモノパイ ルが一般的であり，厚肉の鋼板を巻き太径にしたパ イル(杭)や支持構造（タワー）が用いられ，各部材は ボルト・ナット,溶接, グラウトにより結合される。

この着底式工法は, 波浪の厳しい北海に面する英国 の Blyth, North Hoyle, 及び Scroby Sand なるウイイド アームに適用されている。据付け作業は, 波浪の影響を 受けにくい自己昇降式作業船を用いて行なわれ，壊れ やすい重要部品であるローターやナセルは甲板上を 自走するクローラクレーンで搭載される。それは, 吊 り荷重が数 $100 \mathrm{t}$ と小さいことから成立するものであ るが,船価の高い大型旋廻クレーン船を用いないで棌 む結果，建設費が大幅に縮堿できる。

2) モノタワー

オランダでは石油メジャーの Shell 社が, マージナ ル油田開発のため徹底して上載構造を軽量化し，モ ノタワーをキーとする, 自己昇降式作業船とクローラ クレーンの組合せ施工を実現した。この K17 と呼ばれ るモノタワーは, 水深 $30 \mathrm{~m}$ の海底に直径 $4.2 \mathrm{~m}$ モパ イルを打設しそれに直径 $2.6 \mathrm{~m}$ の円筒状タワーを慗 ぎ,さらにその上に $150 \mathrm{t}$ の油井設備が搭載された。最 終的に，モノタワーは全高 $100 \mathrm{~m}$ となり,重量, 高さ 及び水深の点で,まさに $2 \mathrm{MW}$ 級の洋上風車に匹敵す る。英国でも類似のモノタワーを据付ける海洋建設業 が風車設置に携わっている。

デンマークでは Horns 礁㑖ドフームに続いて, 設備 容量 200MWになる Nysted farm の建設がバルチック海 Röadsand で進められており，これにかかわる Rämboll 社は, 一方でデンマーク沖水深 70mに石油開 発に供するモノタワーを設置している。この国はもっ とも戦略的であり, 風や波浪に対する風力発電施設の 動的解析や疲労評価などの設計面から,気象海象の厳 しい北海での建設作業や維持管理面においてまで, 石 油ガス関連の海洋構造物のノウハウや経験を活用し ながら産官学で積極的に開発を押し進めている。

\section{3）アクセスシステム}

波浪や風が激しい北海では, 維持管理のための洋上 発電施設へアクセスは安全と操業費低減のため重要 
な課題であり,この分野でも石油ガス開発関連の経験 が生かされている。洋上施設への移動は, タワーに設 けられたボートランディングへ作業ボートが係船し 行なわれるのが普通である。しかし, 海が荒れしかも 大規模なウ仆ドァームでは,ヘリコプターからナセルへ， 物資と人を直接降ろす。Viking Life-Saving, Vestas や Rämboll 社等が共同で, 変動する波浪中で乗り降り 可能なボートや最適な係船システムの設計, さらには 浮体式生産設備に用いらてれきたアルミ網製の折り 畳み階段と,海と空からのアクセスシステムを開発し ている。

\section{4) Jチューブ}

プラットフォームで分離された原油やガスを輸送 するための海底パイプラインは, その近くにおいて船 舶アンカーによる引掛け事故や落下物の衝突事故が 多く, パイプラインの立上構造の設計には慎重な注 意を要す。海底ケーブルでも水中基礎と海底間で切断 事故が起こり易いので, Jチューブという保護管に送 電ケーブルを納め敷設される。特に, 潮位差が大きい Scroby Sand のウ价゙ァームでは流れにより海底の洗掘 が生じケーブルの破断が危惧されたので, 送電線を納 めた J チューブが海底のマウンドの中まで埋設され ている。

\section{3. わが国の沿岸の特徵}

\section{1 わが国の沿岸域の広さ}

ここから,わが国沿岸の海底における沿岸の特徵に ついて述べる。

わが国の沿岸は, 概ね海底勾配が急で, 夏季は太平 洋側で冬季は日本側で波浪が厳しく, また台風などの 低気圧の発生が多く, 最大限界風速が大きいという特 徵がある。

さて, 海底に杭で固定される海洋構造物, ジャケッ トが石油ガス開発のため世界中で 8,500 基あまり設 置され,そのうち最も深い記録はメキシコ湾 $450 \mathrm{~m}$ で ある。着底風力発電が経済的に建設できる水哚は, 今 のところ $25 \mathrm{~m}$ までといわれるが, $100 \mathrm{~m}$ までの水深に対 するわが国の海域面積 ${ }^{2)}$ を表-2 に示す。これから分 かるように, 水深 $20 \mathrm{~m}$ 以浅の海域面積は日本の国土面 積 $378,000 \mathrm{~km}^{2}$ の約 1 割の $31,000 \mathrm{~km}^{2}$ に達し，平均離
表-2 わが国の水深別の海域面積

\begin{tabular}{|c|c|c|}
\hline 海域 & 面積 $\left(\mathrm{km}^{2}\right)$ & 平均離岸距離 \\
\hline 国土面積 & 377,720 & $(\mathrm{~km})$ \\
\hline 水深 $0-20 m$ & 30,880 & 0.89 \\
\hline $20--50 m$ & 49,850 & 2.32 \\
\hline $50--100 m$ & 79,740 & 4.61 \\
\hline
\end{tabular}

岸距離は, 海岸線総延長 $34,812 \mathrm{~km}$ で除し $900 \mathrm{~m}$ となる。 これは $50 \mathrm{~m}$ 水深まで広げると $2,300 \mathrm{~m}$ までに拡大する。

ここで一つの試算をしてみたい。仮に $20 \mathrm{~m}$ 以浅の海 底に, $5 \mathrm{MW}$ 機（ローター直径 $\mathrm{D}=120 \mathrm{~m} ）$ を一定面積（10D $\times 3 D ）$ の海域に一基備え付けるとすれば, 約 71,500 箇 所建設できることになる。この数は, 2010年の政府導 入目標值 300 万Wをすべて5MW機でまかなえば, 必要 な施設は600基に過ぎず,如何に大きなものか理解で きよう。

ちなみに, 洋上では設備利用率が $30 \%$ は期待できる ことを考えると, $20 \mathrm{~m}$ 以浅の海から $9.39 \times 10^{11} \mathrm{kWh}$ の年 間発電量が産まれる。これは, わが国の 2005 年度の予 想使用電力量 8620 億kWhに等しい。当然のことではあ るが, 浅水域は物流, 港湾や漁業活動など利用されて いる。そこで, 利用可能な海域を $20 \%$ と見込めば, それ はわが国の石炭火力による発電量に匹敵する。

これだけでも, 着定式洋上風力の可能性はわが国で も小さくないと,ご理解いただけよう。

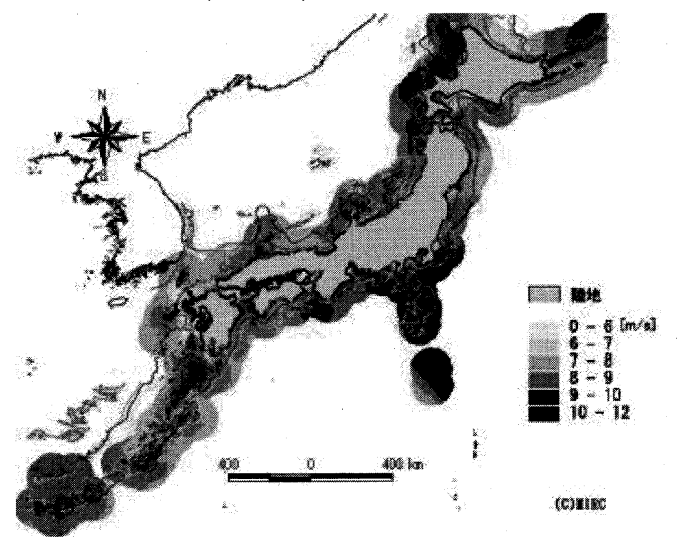

図-2 わが国の周辺の等水深線の分布と風速 ${ }^{5)}$

3. 2 海底勾配

海底勾配が急な海岸が多いといわれる中, 約 $1 \%$ の 緩勾配の海岸を挙げれば, 太平洋側のでは九十九里沿 
岸, 鹿島疑, 有明海であり, 少し急な $2 \%$ 勾配の海岸は 常磐沿岸, 駿河海岸, 遠州灘, 土佐湾などである。日本 海側についても, 新潟西海岸, 秋田県本生海岸が $1 \%$ 勾 配で, 石川県松任海岸, 鳥取皆生海岸が $2 \% 0$ 勾配であ る。これらの多くが風況にも恵まれる。

次に, 平面的広がりと風況を両面から概観するため, 日本近海における水梁 $100 \mathrm{~m}$ 線と予想風速分布を図 -2 に示した。これは，(独）鉄道建設・通輸施設整備支援 機構の援助を受け東海大学含め産官学で進めてきた 浮体式洋上風力発電に関する研究成果 ${ }^{3}$ の一つであ るが,図にあるように $100 \mathrm{~m}$ 等水深線の広がりと,前述 の代表的な遠浅海岸が重なる。総じて, 宗谷海峡, 国後 島周辺, 噴火湾, 仙台湾, 北部九州玄界灘が相当広い。 年平均風速と水深を考虑すると, 留萌, 瀬棚, 秋田, 輸 島, 境港, 屋久島, 那霸, 平良, 石垣, 和歌山, 御前崎, 鹿 島沖及び伊豆大島周辺などが候補地である。

このうちから,陸上の系统の整備状況を勘案し更に 絞ると, 留萌,秋田,御前崎,鹿島沖が適地かと思われる。

\section{4. 着底式洋上風力発電に用いられる水中基礎}

\section{1 水中基礎の種類}

洋上風車を支える水中の基檚は，今のところ着底式 基碳である。これを分類すると,図-3に ${ }^{4)}$ 示すように ヨーロッパの実續ではモノパイル, 重力式, ジャケッ ト(トライポッド)であり,わが国では組杭である。

組杭とは, 例えば 4 脚の鋼管杭を海底に杭打ち機で 打設貫入させ, 杭頭をフーチングと呼ばれる鉄筋コン クリート製の版で結合したものであり,その上に支持 構造である円筒タワーが載る。前揭の図-1 の写真に は, 防波堤内の静皧な水面上に黒色の高密度ポリエ チレンで表面を防食した杭と白色の直方体フーチン グが外観できる。組杭は，海中では波力を受けにくい 構造であるが, 風荷重などによる水平荷重に対しては あまり有利な構造でなく,風が強く荒海象で深い水深 では使われにくい。

重力式基礎は, ヨーロッパで水深が $10 \mathrm{~m}$ 末満の静穞 海域で広く供され, 約 $30 \%$ 実績を占めている。円錐 台状のコンクリート製が多い。これは, 上部の風車や タワーに作用する風荷重やタワーの基部及び水中基 礎に加わる波浪荷重によるせん断力や回転モーメン
・卜に対し, 基礎の自重と幅により滑動や転倒を生じな いよう設計する。鉛直力に対しては沈下や傾斜を起こ さないような海底の地盤強度が大きいところで用い る。しかし，マウンドを設けその上に基礎を筑くので, 水中での搭石の均し作業に多額の費用を要す。

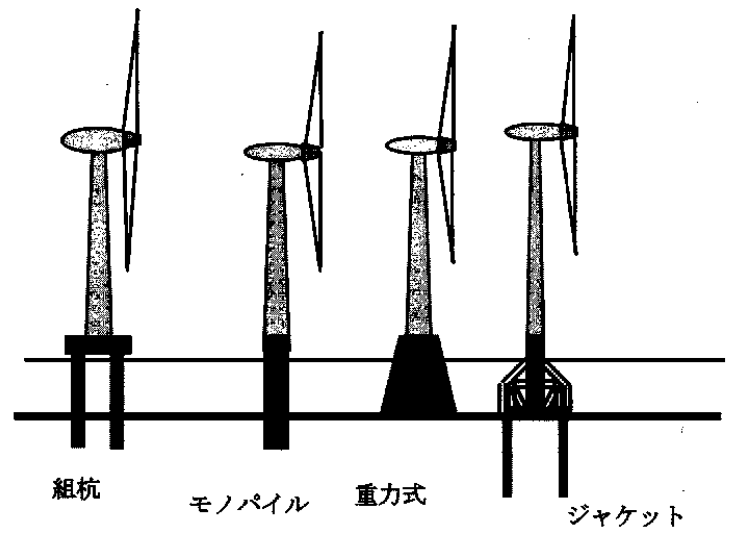

図-3 着底式洋上風力発電のための水中基䃈

最近, 沖合のより樑い水樑で建設されるようになる と, 4-5m直径の太径鋼管杭基䃈であるモノパイルが

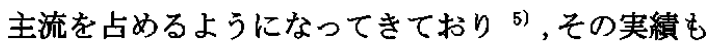
60\%を上回る。モノパイルは $70 \mathrm{~mm}$ 程度にもなる厚鋼板 から造られ, 通常, 杭打ハンマーにより海底下 20 30mに打ち込まれる。油圧で作動するハンマーが打設 できる杭の最大直径は約 $1.8 \mathrm{~m}$ である。そのため，太 いモノパイルに対応するため, 特殊な拡幅継ぎピース を使用する。このピースの径が変化する部分では, 八 ンマーの打揧力が減衰し十分に杭に伝達されず, 地盤 によっては杭が打ち込めなくなる。そのため, 途中ま で貫入した杭の内側を中堀し，内部の土砂を取り除い てさらにハンマーで所定の根入れ長さを確保するま で打ち込むこともある。杭が打設できないような硬質 地盤では, 掘削により太径の立坑を築造しその中に杭 を挿入し, 最後にモルタルグラウトにより杭と地盤を 一体化する。

一例の実績があるが特殊な杭としては 5-6m の円 筒状のサクション杭がある。これは口元が狭く次第に 広がるラッパ形状をしており,底側が開口し海底に膡 かれると自重で少し貫入する。ついで, 海底と杭内部 にある海水をポンプで吸引すると土砂もろとも吸い 上げられて, その結果杭は哚く入る。比較的簡便な設 
備で, 砂でも粘土地盤でも急速施工でき, 浮体のアン カーとしてまた固定式海洋構造物の基礎として一部 使われてきた。

トライポッドと呼ばれる三脚ジャケットも, 現在の ところ実績が一例あるだけであるけれども使われた。 ジャケットは海底面上の複数本の杭を東ねることで, 㣚性を高め, 風や波がもたらす水平荷重や曲げモー メントに効果的に抵抗し,風車やタワーの自重を地盤 に伝達するものである。また,その鞄性も高いので耐 震性に優れることから,わが国のような地震が多く， 猛烈な風を送り込む台風が頻繁に来襲するところで は有力な水中基礎となりえると期待される。

\section{5. 今後の展望}

洋上及び沿岸域で風車を建設しようとすると, 連結 すべき陸上の系統の受け入れ状況, 海上占有に伴う諸 規制, 漁業問題等様々な克服すべき課題があり, 本格 的な洋上風車立国を目指すためには,これらを一つひ とつ解決していかねばならない ${ }^{6)}$ 。(財) 沿岸技術研究 センターの場でも, 港湾域及びその沖合の活用のため の推進策が産官学で研究されてきた ${ }^{7)}$ 。

ここでは紙面の関伱からそのような議論は割愛し， 洋上立地でコストダウンに不可欠な大型洋上発電の ための支持構造と水中基礎に絞って展望する。

\section{1 トラスタワーの可能性}

過去, 陸上ではラティスという送電鉄塔に似た支持 構造が採用されていたが,これに鳥が巣を作る, 部材 数が多くて組み立て工程が長くなる, 等の理由で次第 に, 小型の陸上風車を除いて, ラティス構造は姿を消 してきた。しかしながら,ダウンウィンド風車では勿 論, アップウインド風車でも, 後流城での流れが阻害 されにくい透過性の高いラティス構造は, 発電効率や 振動影響の点でそのメリットは棄てがたい。

\section{1）大型化に伴う疲労問題}

スケールメリット追求の結果, 発電機が大型化して くると洋上風車全体の曲げ 1 次固有周期は長くなる。 その結果,水平変位が大きくなり,支持構造の疲労問 題が顕在化する。大型化に伴い, ナセルとローターの 質量やナセルの高さが増加し,さらに風車全体の受け る風荷重も増える。同時に支持構造や水中基礎も大型

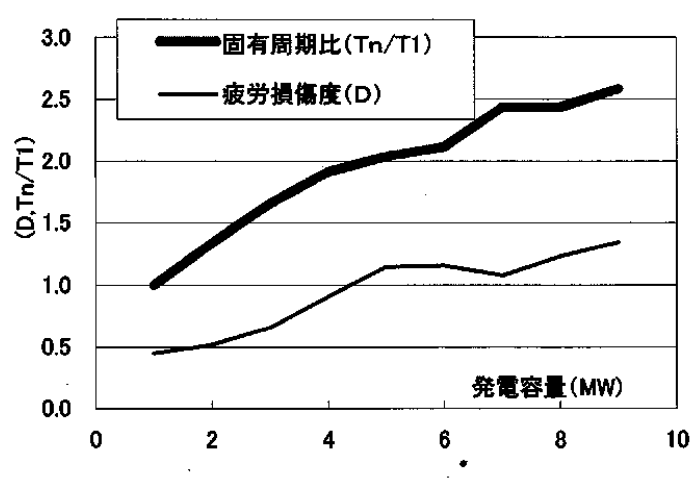

図-4 大型化に対する固有周期と疲労損傷

化により作用する波力も増大する。このような前提の 元に実施した笔者らの研究では, 1 次固有周期は,図-4 のように $1 \mathrm{MW}$ 機に対し $5 \mathrm{MW}$ 機では 2 倍の $5-6 \mathrm{~s}$, $9 \mathrm{MW}$ 機では 7-8s と台風時の波浪周期に近づく。そ の結果,固有周期と同調し易く疲労損傷度も増加する。 ある海域での海気象出現頻度から, 波浪と風荷重に 対する時間領域の動的解析を行い,レインフロー計数 により応力範囲の出現回数を求め, マイナー則によ って支持構造の疲労損傷度を推算した ${ }^{8}$ 。

結論として,大型化は疲労寿命を損なう。疲労損傷 度はサイトサイトの自然環境条件で異なるものの,こ のような傾向は一般性があり,大型の風車を搭载する ようになると支持構造の疲労対策が必要となる。

2）高剛性支持構造

着底・浮体式に関わらず, 波浪や風による変動荷重 周期との同調を避け,振動軽減や疲労損傷の軽減する 必要がある。着底式の場合はさらに地震も含め,制振・ 免震対策4)も求められよう。

そのため,篻者は図-5 のような従来の太径モノタワ 一に変わる中径鋼管でトラスを組んだ支持構造によ り,この問題を対処できないかと考えている。

モノタワーは剛性強化が必要な結果, タワーの直径 は $5 \mathrm{MW}$ 規模では $7 \mathrm{~m}$ 程度であるものが, 将来 $8 \mathrm{MW}$ 以 上になると高張力鋼により $90 \mathrm{~mm}$ 程度と薄肉化を期 待できるものの直径は $10 \mathrm{~m}$ 程度になると試算 ${ }^{8)}$ され る。モノタワーでは長くなりやすい固有周期をトラス にすることで約 7 割と短くできる。これには鋼材重量 の増加は免れないが,疲労は大きく軽減するので将来 の大型化に弾みがつくものと期待できる。 


\section{2 新型基礎}

十分な剛性と強度を有し風の力を受けにくい形状 であるべき支持構造は,さらに現地の様々な土質に適 応し,勒性や变形性能も望まれる。そこで,強度や剛性 面からモノパイルに代わる太径の水中基礎の候補と して, 前述のサクション杭があげられる。二つ目は, 国内で橋梁の基礎に用いられる鋼管矢板井筒基礎で あろう ${ }^{7)}$ 。後者は鋼管中径の鋼管矢板を連結し鉄筋コ ンクリートの上部工からなり, 海底地盤と一体になり 大きな剛性が得られる。洋上では, 急速施工が求めら れるのでこれを解決した施工法は不可欠である。

5.3 タワーと基礎の一体化

タワー直径に対応し基礎も大型化する。これを克服 し, 同時に勒性や変形性能を向上させるため，筆者は 図-5 のようなアイデアを提案している。一つは, 現状 のモノパイルをガイドケーブルで補強し剛性をあげ る。二つ目は, 打設限界に相当するような直径の杭を 用いたジャケット基礎にする。しかも, 支持構造と水 中基礎を一体化する。この場合, ラティスのような複 雑な支持構造は施工や腐食の面で不利と思われるの で,より単純化した鋼管トラスとジャケットを組合せ た着底式支持構造が最適と考えており, 現在風洞実験 等で検証しているところである。

結論としては,今後もっとトラスやラティス支持構 造を活用されるのではないかと予想している。

\section{6. 最後に}

わが国には, 陸域に送電線が整備され, 離岸距離が 短く着底式基礎が経済的に建設される遠浅な海岸は 少なくない。勿論, そのような条件を満たしながらも 急深な海域もある。したがって, 着底・浮体式にとら われず, 相互の技術的課題を克服しながら, 経済的で 合理的な基礎を開発すべきものと思う。そのために， 機械・電気・造船・土木という垣根を超え, 産官学の 知恵や力を結集しながら研究開発を進め,わが国本格 的な洋上発電を実現することを願うものである。

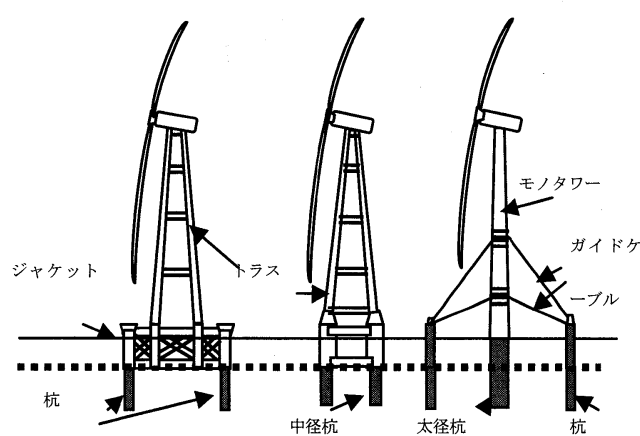

図-5 支持構造と水中基礎の融合案

参考文献

1) Offshore Engineer, "Wind can learn from oil",pp.12-13, ,March,2004, " Centered thinking on Knowledge Hil1" , pp.x-xi,Sep.,2005

2）磯部雅彦, "日本の海岸の現状と問題点. 海岸の環 境創造ーウオーターフロント学入門一”, 朝倉書 店, pp. 1-8, 1994

3）大川豊, 矢後清和, 太田真, 山田義則, 高野宰, 関田欣 治,”代替燃料創出を目指した浮体式風力発電施設 に関する基礎的研究”, 土木学会, 海洋開発論文 集, VOL. 20, pp. 1217-1222, 2004

4) 関田欣治,”着底型洋上風力発電の動的設計に関わ 万研究”, (独) 海上技術安全研究所, (独) 鉄道建設. 運輸施設整備支援機構, 洋上風力発電フォーラム講 演集, pp. 110-116, 2004

5) N.F.Gjersoe, "Design of monopole foundations for large offshore windturbines -Experiences from the first projects offshore the British coast", Proc. of $15^{\text {th }}$ ISOPE, pp.433-440,2005

6）関田欣治, “産声上げた洋上風力発電”, エネルギ 一, 12 月号, pp. 72-76, 2004

7）(財) 沿岸研究センター, “港湾・沿岸域における風 力発電推進に関寸る研究報告書” , 平成 17 年 2 月

8) A.Yamashita, and K.Sekita, "Analysis of the fatigue damage on the large scale offshore wind turbines exposed to wind and wave loads", Proc. of 14th International Offshore and Polar Engineering Conference, pp.166-171, 2004 